Jurnal Kimia Sains dan Aplikasi 21 (2) (2018): 80-84
ISSN: 1410-8917
Jurnal Kimia
Aplikasi

\title{
Chitosan succinate/PVA-PEG Membrane: Preparation, Characterization and Permeation Ability Test on Creatinine
}

\author{
Retno Ariadi Lusiana ${ }^{a^{*}}$, Vivi Dia Ahmad Sangkota ${ }^{a}$, Sri Juari Santosa ${ }^{\mathrm{b}}$ \\ a Chemistry Department, Faculty of Sciences and Mathematics, Diponegoro University, Jalan Prof. Soedarto, Tembalang, Semarang \\ b Chemistry Department, Faculty of Mathematics and Natural Sciences, Gadjah Mada University, Yogyakarta \\ * Corresponding author: retno.lusiana@live.undip.ac.id
}

\begin{tabular}{l} 
Article Info \\
\hline Keywords: \\
chitosan-succinate \\
membranes; poly \\
vinyl alcohol; poly \\
ethylene glycol; \\
permeation ability; \\
creatinine
\end{tabular}

Kata Kunci:

membran kitosansuksinat; poli vinil alkohol; poli etilen glikol; kemampuan permeasi; kreatinin

\begin{abstract}
Evaluation character of chitosan membrane-succinate / poly vinyl alcohol-poly ethylene glycol (PVA-PEG) were prepared in acetic acid solvent through a phase inversion method has been performed. The study began with the preparation of crosslinked chitosan compounds with succinic acid, followed by preparation into membrane by combining PVA-PEG. Character analysis of the resulting material using FTIR, EDX, TGA, water absorption test, tensile strength, membrane hydrophilicity. The ability of membrane permeation was tested against creatinine. The results showed that the succinate had reacted with chitosan. Chitosan modification through cross link and polymer alloys increases tensile strength and membrane strain of 1.7-2.5 $\mathrm{x}$ of pure chitosan membrane. In addition, the modified membrane also has higher water absorption and hydrophilicity values than the unmodified membrane, and this implies the ability of membraneinduced creatinine permeation. Permeable permeation values were $13.8 \%$ in chitosan, $24.84 \%$ on chitosan-succinate and $25 \%$ in chitosan-succinate / PVA-PEG. Chitosansuccinate membranes have the ability to use more than $4 \mathrm{x}$ repeated use.
\end{abstract}

\section{Abstrak}

Evalusi karakter dari membran kitosan-suksinat/poli vinil alkohol-poli etilen glikol (PVA-PEG) yang disiapkan dalam pelarut asam asetat melalui metoda inversi fasa telah dilakukan. Penelitian diawali dengan pembuatan senyawa kitosan yang bertaut silang dengan asam suksinat, dilanjutkan preparasi menjadi membran dengan memadukan menggunakan PVA-PEG. Analisis karakter dari material yang dihasilkan menggunakan FTIR, EDX, TGA, uji penyerapan air, kuat tarik, hidrofilisitas membran. Kemampuan permeasi membran diujikan terhadap kreatinin. Hasil analisis menunjukkan bahwa suksinat telah bereaksi dengan kitosan. Modifikasi kitosan baik melalui taut silang dan paduan polimer meningkatkan kuat tarik dan regangan membran sebesar 1,7-2,5 $\mathrm{x}$ dari membran kitosan murni. Selain itu, membran termodifikasi juga memiliki nilai serapan air dan hidrofilisitas yang lebih tinggi dibandingkan membran tanpa modifikasi, dan hal ini berimplikasi terhadap kemampuan permeasi kreatinin oleh membran. Nilai permeasi berturut-turut adalah $13,8 \%$ pada kitosan, $24,84 \%$ pada kitosan-suksinat dan $25 \%$ pada kitosan-suksinat/PVA-PEG. Membran kitosan-suksinat mempunyai kemampuan penggunaan lebih dari $4 \mathrm{x}$ pemakaian berulang.

\section{Pendahuluan}

Desain struktur membran sangat penting dalam mengembangkan membran dengan kinerja tinggi. Kitosan merupakan biopolimer yang dapat dijadikan material dasar membran karena dapat larut dalam asam encer dan membentuk film tipis membran melalui proses inversi fase. Akan tetapi, membran kitosan pure tidak cukup reaktif terhadap senyawa target karena 
kurangnya jumlah sisi aktif penangkap permeat. Pembuatan membran berbasis kitosan selanjutnya dikembangkan melalui modifikasi struktur dan permukaan dari kitosan [1].

Modifikasi struktur terhadap kitosan harus memperhatikan beberapa aspek, seperti: gugus fungsi [2], selektivitas dan fleksibilitas [3] material hasil modifikasi ketika diaplikasi sebagai membran permeasi. Dalam proses permeasi terhadap kreatinin oleh membran berbasis kitosan termodifikasi, dibutuhkan suatu modifier yang bisa menciptakan ikatan hidrogen yang cukup kuat antara kreatinin dengan sisi aktif, agar kreatinin dapat melewati membran dengan cepat $[2,4$, 5]. Beberapa gugus fungsi telah digunakan sebagai modifier dalam proses permeasi kreatinin, seperti asam sitrat $[1,6]$, tripolifosfat $[2,7,8]$.

Asam suksinat merupakan asam dikarboksilat, banyak digunakan untuk keperluan industri farmasi karena bersifat hidrofil dan non-toksik. Gugus karboksilat (-COO-) dari asam suksinat akan berikatan dengan gugus $-\mathrm{NH}_{2}$ dari kitosan membentuk ikatan taut silang (crosslink) yang dapat menata jarak antara polimer kitosan satu dengan lainnya untuk membentuk struktur yang lebih rapi dalam bentuk struktur jaring. Struktur jaring yang tertata ini selanjutnya akan membuat kreatinin lebih mudah melewati membran. Selain itu adanya gugus -O bebas dari modifier akan berfungsi sebagai sisi aktif yang akan menangkap kreatinin secara selektif dan cepat.

Fleksibilitas membran dibutuhkan untuk menjaga stabilitas membran ketika berada dalam lingkungan berair dalam waktu tertentu. Modifikasi dengan gugus karboksilat meningkatkan hidrofilisitas senyawa kitosan, karena adanya ikatan hidrogen dengan molekul air. Hidrofilisitas yang terlalu tinggi dapat membuat membran akan rapuh dan mudah sobek. Untuk meningkatkan kekuatan mekanik senyawa yang akan dibuat menjadi membran, maka dilakukan pemaduan menggunakan polimer sintetik seperti poli vinil alkohol (PVA) poli etilen glikol (PEG) [9] dan poli vinil acetate [10].

Dalam penelitian ini dilakukan sintesis kitosan taut silang suksinat (CS-Suk), pemaduan menggunakan PVA/PEG untuk membuat membran melalui proses inversi fasa. Membran CS-Suk/PVA-PEG diuji kemampuan dan penggunaan berulang membran pada proses permeasi terhadap kreatinin.

\section{Metodologi Penelitian}

\section{Bahan}

Kitosan dengan deasetilasi 89\%, didapatkan dari PT Surindo Tech, Cirebon Indonesia. Asam suksinat, asam asetat, $\mathrm{NaOH}$, kreatinin, buffer fosfat, poli vinil alkohol, poli etilen glikol asm pikrat didapatkan dari Merck.

Persiapan Pembuatan Komposit Kitosan/Sitrat Dan Kitosan/Suksinat

Serbuk PVA/PEG dimasukkan dalam $100 \mathrm{~mL}$ akuades hangat diaduk selama 2 jam pada suhu $\pm 60^{\circ} \mathrm{C}$.
Serbuk kitosan/suksinat dimasukkan ke $100 \mathrm{~mL}$ larutan asam asetat $1 \%$ dan diaduk menggunakan pengaduk magnet pada waterbath air mendidih selama 4 jam. Selanjutnya kedua larutan dicampur pada rasio tertentu (CS-Suk,75/PVA-PEG,25) untuk membuat membran CS-Suk/PVA-PEG. Membran dicetak menggunakan cawan petri, dan dikeringkan di oven pada suhu 50$70^{\circ} \mathrm{C}$. Membran yang sudah kering dilepaskan dan dicuci dengan akuades sampai netral.

\section{Karakterisasi Membran}

Karakterisasi: gugus fungsi membran menggunakan FTIR, EDX, stabilitas termal menggunakan TGA, serapan terhadap air, fleksibiltas dan kelenturan, ketebalan membran menggunakan thicknessmeter.

\section{Uji Permeasi Terhadap Kreatinin}

Uji permeasi dilakukan menggunakan alat permeasi, yang di tengahnya terdapat sebuah membran. Fasa sumber berisi $50 \mathrm{~mL}$ larutan standar kreatinin 25 ppm dalam larutan buffer fosfat dan fasa akseptor berisi $50 \mathrm{~mL}$ buffer fosfat. Permeasi dilakukan selama 6 jam dengan setiap jam diambil $2 \mathrm{~mL}$ sampel dari fasa sumber dan akseptor yang kemudian dikompleks menggunakan asam pikrat dan dianalisis menggunakan spektrofotometer UV-Vis pada panjang gelombang 486 nm.

\section{Hasil dan Pembahasan}

Seluruh membran yang dibuat memiliki kenampakan tipis, transparan, dengan tebal antara $10^{-}$ ${ }^{2} \pm 2 \mathrm{~mm}$. Ada beberapa metode pembuatan membran, diantara adalah sintering, streaching, track-etching, template leaching dan inversi fasa. Pada penelitian ini pembuatan membran dilakukan dengan proses inversi fasa. Inversi fasa adalah metode yang paling banyak digunakan dalam pembuatan membran polimer untuk proses pemisahan, karena kemudahan dan reproducible yang tinggi. Pada metode ini, polimer bentuk padatan diubah ke bentuk larutan dan kembali diubah ke bentuk padatan secara terkontrol pada suhu dan waktu tertentu Proses pemadatan sangat sering diawali dengan perpindahan polimer dari suatu cairan (pelarut) ke cairan lain (non pelarut) dilanjutkan dengan evaporasi larutan berlebih. Fase dengan konsentrasi polimer yang tinggi dalam larutan polimer akan membentuk padatan atau matriks membran, sedangkan fase dengan konsentrasi polimer yang rendah akan membentuk pori-pori [11].

\section{Karakterisasi Kimia Senyawa Kitosan-Suksinat (CS-} Suk)

Keberhasilan taut silang antara kitosan dengan asam suksinat diperlihatkan oleh spektra pada Gambar 1. Pada spektra spesifik kitosan terlihat serapan pada daerah $3400 \mathrm{~cm}^{-1}$ yang merupakan serapan gugus $-\mathrm{OH}$ dan $-\mathrm{NH}$ yang berhimpit. Serapan kembar gugus $-\mathrm{NH}_{2}$ primer akan terlihat pada daerah 1600 dan $1658 \mathrm{~cm}^{-1}$. Serapan lemah di daerah $1059 \mathrm{~cm}-1$ yang merupakan serapan gugus $-\mathrm{C}-\mathrm{O}$. Setelah mengalami reaksi taut silang, maka terjadi pergeseran serapan yang dapat 
dilihat pada daerah sekitar $1750 \mathrm{~cm}^{-1}$, dimana serapan kembar $-\mathrm{NH}_{2}$ akan hilang, sebagai gantinya muncul serapan tunggal gugus $\mathrm{C}=0$. Pada daerah $3400 \mathrm{~cm}^{-1}$ terjadi pergeseran serapan yang merupakan indikasi, perubahan gugus pada - NH primer menjadi - NH sekunder atau tersier. Selain itu, pada daerah 1060 dan $1025 \mathrm{~cm}^{-1}$ muncul puncak yang cukup tajam, yang menunjukkan serapan gugus $\mathrm{C}-\mathrm{O}$ dari asam suksinat yang menempel pada kitosan $[2,6,12]$

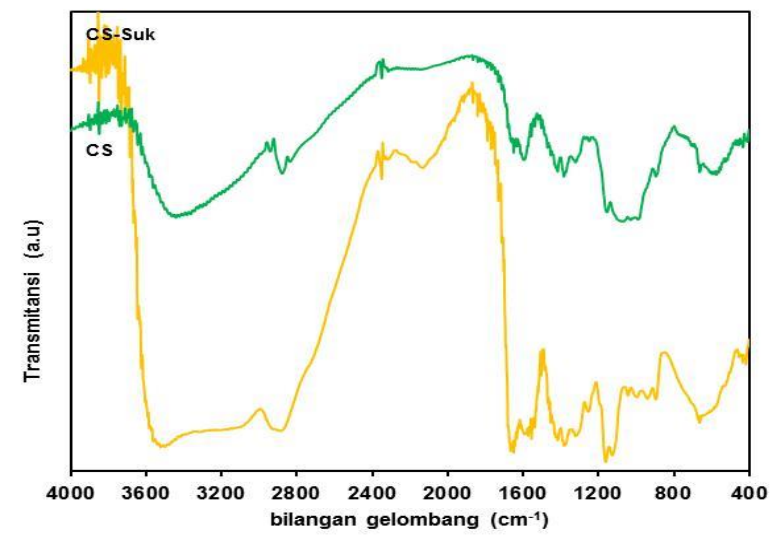

Gambar 1. Spektra FTIR membran kitosan dan kitosansuksinat
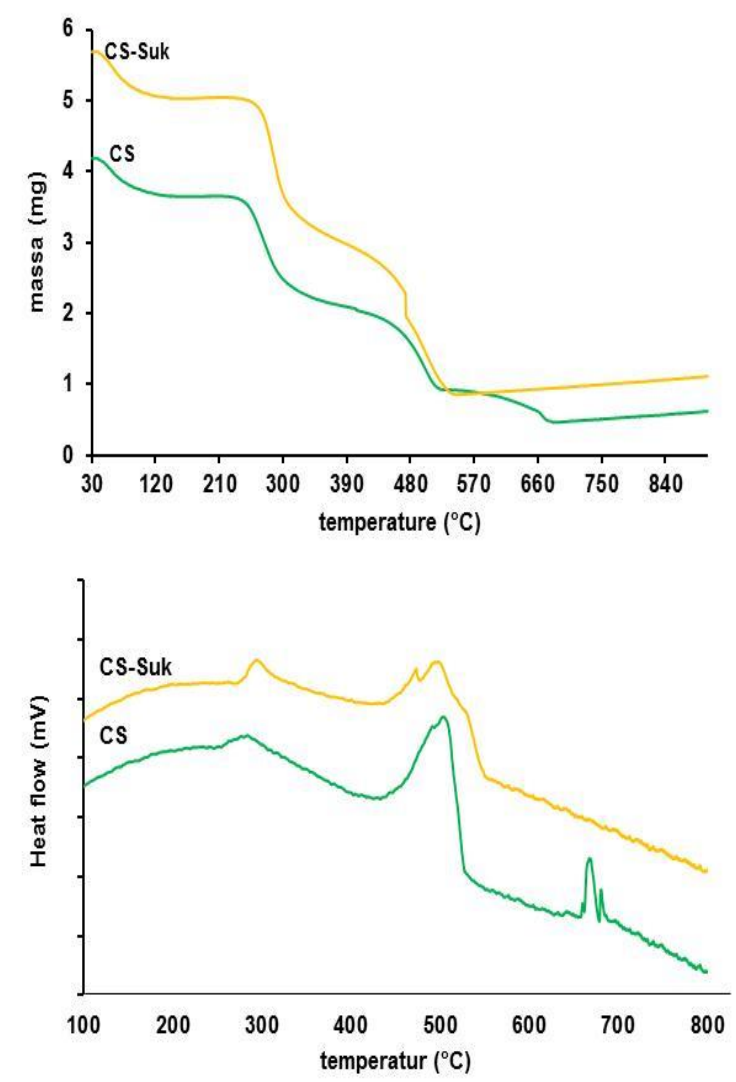

Gambar 2. Termogram membran kitosan dan kitosan suksinat

Analisis termogravimetri dilakukan pada kisaran temperatur antara $30-900^{\circ} \mathrm{C}$ dengan kecepatan keanikan suhu $5^{\circ} \mathrm{C} /$ menit. Pada termogram terlihat perbedaan kisaran suhu pada penurunan berat stage pertama. Reaksi taut silang, membuat keteraturan jarak dalam struktur polimer, keteraturan jarak membuat proses pemutusan ikatan menjadi lebih mudah dan menurunkan stabilitas termal senyawa modifikasi [13]. Untuk mempertegas interprestasi hasil reaksi cangkok dilakukan analisis elemen menggunakan EDX, seperti terlihat pada Tabel 1.

Tabel 1. Persentase komposisi elemen membran

\begin{tabular}{ccccc}
\hline Membran & $\begin{array}{c}\text { Karbon } \\
(\%)\end{array}$ & $\begin{array}{c}\text { Oksigen } \\
(\%)\end{array}$ & $\begin{array}{c}\text { Hidrogen } \\
(\%)\end{array}$ & $\begin{array}{c}\text { Nitrogen } \\
(\%)\end{array}$ \\
\hline CS & 42,1 & 38,8 & 7,0 & 7,8 \\
CS-Suk & 42,2 & 40,0 & 6,0 & 7,1 \\
\hline
\end{tabular}

Dari analisis data secara kimia, dapat digambarkan perkiraan reaksi kimia yang terjadi antara kitosan dengan asam suksinat, seperti terlihat pada Gambar 3.

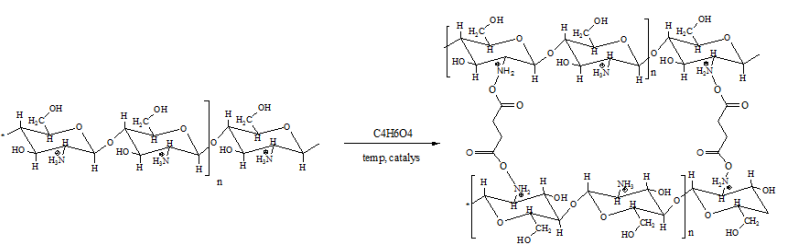

Gambar 3. Perkiraan reaksi taut silang kitosan - asam suksinat

\section{Karakterisasi Fisika Membran CS-Suk/PVA-PEG}

\section{Uji serapan terhadap air dan hidrofilisitas membran}

Uji serapan terhadap air merupakan uji penting untuk mengetahui karakter membran yang dibuat. Dalam proses permeasi, kreatinin dilarutkan dalam lingkungan air, oleh karena itu membran yang akan digunakan harus memiliki kemampuan serapan terhadap air agar mampu melakukan permeasi terhadap kreatinin. Dari data pada Tabel 1 terlihat bahwa proses modifikasi terhadap kitosan dengan senyawa suksinat, menaikkan kemampuan serapan air membran hingga $300 \%$. Masuknya gugus $-\mathrm{COOH}$ dari suksinat dan $-\mathrm{OH}$ dari PVA dan PEG, membuat kemampuan membran berinteraksi dengan air meningkat, dengan terbentuknya ikatan hidrogen dengan molekul air [14, 15]. Dengan demikian dapat dikatakan bahwa hidrofilisitas membran meningkat. Hal ini juga tercermin dari nilai sudut kontak membran yang semakin menurun dari nilai sudut kontak kitosan.

Tabel 2. Karakteristik fisika membran

\begin{tabular}{ccccc}
\hline Membran & $\begin{array}{c}\text { Sudut } \\
\text { Kontak } \\
\left({ }^{\circ}\right)\end{array}$ & $\begin{array}{c}\text { Serapan } \\
\text { air }(\%)\end{array}$ & $\begin{array}{c}\text { Kuat } \\
\text { tarik } \\
(\mathrm{MPa})\end{array}$ & $\begin{array}{c}\text { Regangan } \\
(\%)\end{array}$ \\
\hline CS & 85 & 89 & 1,40 & 16,8 \\
CS-Suk & 50 & 230 & 1,25 & 25,2 \\
$\begin{array}{c}\text { CS- } \\
\text { Suk/PVA- } \\
\text { PEG }\end{array}$ & 45 & 250 & 1,25 & 42,0 \\
\hline
\end{tabular}




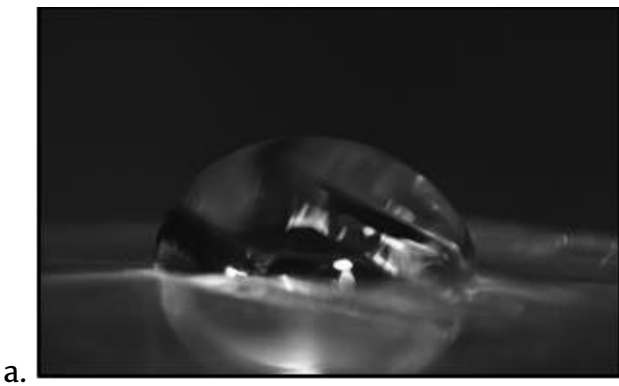

b.
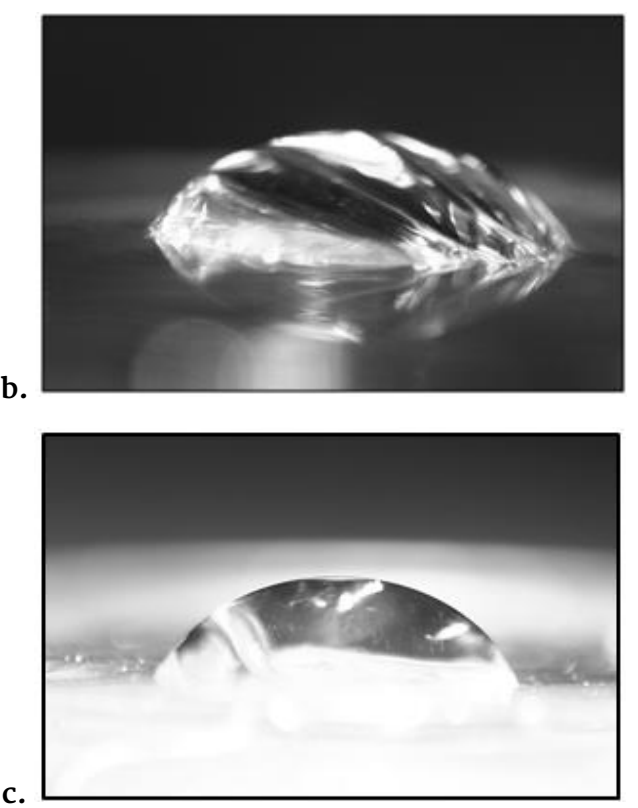

Gambar 4. Sudut kontak membran kitosan (A), CS-Suk (B), CS-Suk/PVA-PEG (C)

\section{Uji regangan membran}

Uji regangan dilakukan untuk mengetahui kekuatan regang dan fleksibilitas membran ketika diberi suatu gaya tarik dari luar, yang dapat merusak struktur membran. Semakin teratur struktur membran, maka membran akan mempunyai kuatan tarik dan regang yang tinggi. Dari data Tabel 2, terlihat bahwa reaksi taut silang meningkatkan kekuatan regang dari kitosan. Demikian juga ketika kitosan taut silang suksinat dipadukan dengan PVA-PEG, terlihat bahwa penambahan polimer sintetik ini menaikkan kekuatan mekanik membran dengan meningkatkan daya regang (fleksibilitas) membran menjadi 1,7 x dari kitosansuksinat atau 2,5 x kekuatan regang membran kitosan. Hal ini, mengindikasi bahwa taut silang membuat keteraturan jarak antara polimer satu dengan lainnya, sehingga ikatan interpolimer menjadi lebih kuat. Dengan kuatnya gaya interpolimer tersebut maka membran tidak mudah rusak oleh pemberian gaya dari luar [16].

Uji permeasi terhadap kreatinin

Studi kemampuan permeasi terhadap kreatinin dilakukan selama 6 jam pada setiap kali pemakaian. Hasil permeasi kreatinin pada pemakaian pertama terlihat pada Gambar ...Dari data terlihat bahwa permeasi oleh kitosan tertaut silang suksinat menaikkan kemampuan permeasi pada membran kitosan. Sedangkan pemaduan dengan PVA-PEG tidak menaikkan kemampuan permeasi membran termodifikasi secara signifikan. Reaksi taut silang kitosan dengan asam suksinat menyebabkan gugus yang berperan sebagai sisi aktif membran bertambah, yaitu dengan masuknya gugus - $\mathrm{COO}$ - dari asam suksinat. Gugus -O- bebas dari - $\mathrm{COO}$ - menyebabkan kemampuan menarik kreatinin melalui terbentuknya ikatan hidrogen menjadi lebih besar [6]. Hal ini menyebabkan permeasi kreatinin meningkat dibandingkan dengan permeasi pada membran kitosan pure.

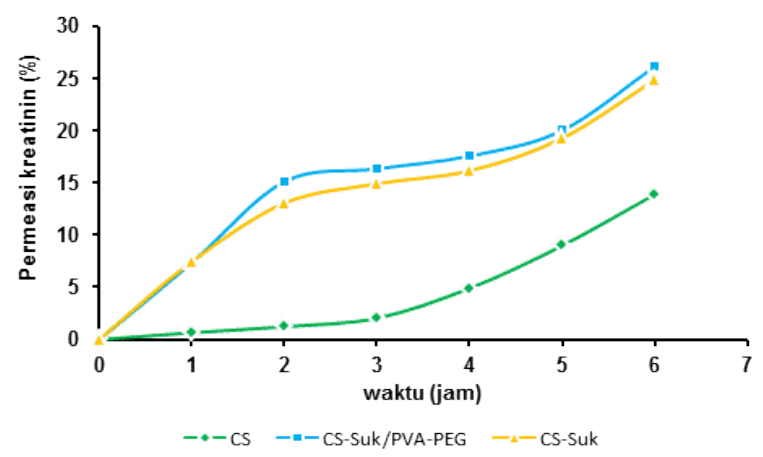

Gambar 5. Permeasi membran terhadap kreatinin

Uji penggunaan berulang (reuse) membran CS-Suk dilakukan selama lima kali pemakaian, terlihat pada Gambar 6. Dari uji reuse tersebut, didapatkan persentase permeasi kreatinin berturut-turut adalah 24,84, 24,62, 23,99, 23,21 dan 22,96\%. Tidak terjadi penurunan persentase secara signifikan, dalam penggunaan secara berulang membran, hal ini mengindikasi bahwa membran cukup baik dalam kestabilan sisi reaktifnya.

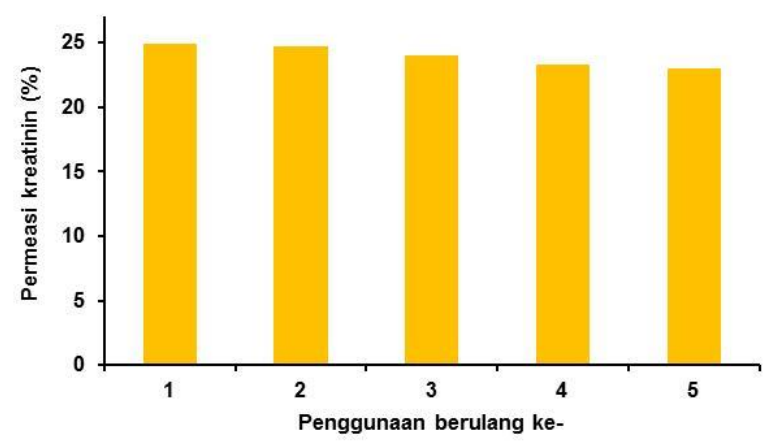

Gambar 6. Permeasi kreatinin pada penggunaan berulang (reuse) membran CS-Suk

\section{Ucapan terimakasih}

Penelitian ini didanai oleh Dirjen Pendidikan Tinggi melalui program penelitian Pascadoktor.

\section{Kesimpulan}

Modifikasi kitosan melalui taut silang dengan gugus - $\mathrm{COOH}$ dari asam suksinat dan paduan dengan polimer sintetik PVA-PEG mampu meningkatkan kekuatan fisika, kimia dan kemampuan permeasi terhadap kreatinin. 


\section{Daftar Pustaka}

[1] Retno Ariadi Lusiana, Dwi Siswanta, Mudasir Mudasir, Preparation of Citric Acid Crosslinked Chitosan/Poly(Vinyl Alcohol) Blend Membranes for Creatinine Transport, Indonesian Journal of Chemistry, 16, 2, (2018) 144-150 http://dx.doi.org/10.22146/ijc.21157

[2] Retno Ariadi Lusiana, Wahyu Putri Protoningtyas, Anugrah Ricky Wijaya, Dwi Siswanta, Mudasir, Sri Juari Santosa, Chitosan-Tripoly Phosphate (CSTPP) Synthesis Through Cross-linking Process: the Effect of Concentration Towards Membrane Mechanical Characteristic and Urea Permeation, Oriental Journal of Chemistry, 33, 6, (2017) 2913-2919 http://dx.doi.org/10.13005/0jc/330626

[3] Ezequiel S. Costa-Júnior, Edel F. Barbosa-Stancioli, Alexandra A. P. Mansur, Wander L. Vasconcelos, Herman S. Mansur, Preparation and characterization of chitosan/poly(vinyl alcohol) chemically crosslinked blends for biomedical applications, Carbohydrate Polymers, 76, 3, (2009) 472-481

https://doi.org/10.1016/j.carbpol.2008.11.015

[4] Wilma F. van Straaten-Nijenhuis, Feike de Jong, David N. Reinhoudt, Randolph P. Thummel, Thomas W. Bell, Jia Liu, Urea transport through supported liquid membranes using synthetic carriers, Journal of Membrane Science, 82, 3, (1993) 277-283 https://doi.org/10.1016/0376-7388(93)85192-Y

[5] H. M. Fahmy, Moustafa M. G. Fouda, Crosslinking of alginic acid/chitosan matrices using polycarboxylic acids and their utilization for sodium diclofenac release, Carbohydrate Polymers, 73, 4, (2008) 606611 https://doi.org/10.1016/j.carbpol.2007.12.024

[6] Fathur Al Baani, Retno Ariadi Lusiana, Muhammad Cholid Djunaidi, Pengaruh Agen Pencangkok Heparin terhadap Kemampuan Transpor Kreatinin dan Urea Membran Turunan Kitosan, Jurnal Kimia Sains dan Aplikasi, 20, 2, (2017) 92-94 http://dx.doi.org/10.14710/jksa.20.2.92-94

[7] Magdalena Gierszewska, Jadwiga OstrowskaCzubenko, Chitosan-based membranes with different ionic crosslinking density for pharmaceutical and industrial applications, Carbohydrate Polymers, 153, (2016) 501-511 https://doi.org/10.1016/j.carbpol.2016.07.126

[8] Nastiti Nastiti, Parsaoran Siahaan, Pengaruh Berat Molekul Kitosan terhadap Efisiensi Enkapsulasi BSA (Bovine Serum Albumin) Menggunakan Agen Crosslink Na-TPP, Jurnal Kimia Sains dan Aplikasi, 18, 3, (2015) 104-109

[9] M. N. Hyder, P. Chen, Pervaporation dehydration of ethylene glycol with chitosan-poly(vinyl alcohol) blend membranes: Effect of CS-PVA blending ratios, Journal of Membrane Science, 340, 1, (2009) 171-180 https://doi.org/10.1016/j.memsci.2009.05.021

[10] Radhakumary C., Nair Prabha D., Reghunadhan Nair C. P., Mathew Suresh, Chitosan-graft-poly(vinyl acetate) for hemodialysis applications, Journal of Applied Polymer Science, 125, 3, (2012) 2022-2033 http://dx.doi.org/10.1002/app.36261

[11] Marcel Mulder, J. Mulder, Basic Principles of Membrane Technology, Springer, 1996.
[12] Suneeta Kumari, Sri Hari Kumar Annamareddy, Sahoo Abanti, Pradip Kumar Rath, Physicochemical properties and characterization of chitosan synthesized from fish scales, crab and shrimp shells, International Journal of Biological Macromolecules, 104, (2017) 1697-1705 https://doi.org/10.1016/j.ijbiomac.2017.04.119

[13] Lulu Li, Chong Cheng, Tao Xiang, Min Tang, Weifeng Zhao, Shudong Sun, Changsheng Zhao, Modification of polyethersulfone hemodialysis membrane by blending citric acid grafted polyurethane and its anticoagulant activity, Journal of Membrane Science, 405-406, (2012) 261-274 https://doi.org/10.1016/j.memsci.2012.03.015

[14] Peng-bo Huangfu, Ming Gong, Cunfu Zhang, Shan Yang, Jiang Zhao, Yong-kuan Gong, Cell outer membrane mimetic modification of a cross-linked chitosan surface to improve its hemocompatibility, Colloids and Surfaces B: Biointerfaces, 71, 2, (2009) 268-274 https://doi.org/10.1016/j.colsurfb.2009.02.014

[15] Agustiani Yudi Aryanti, Rum Hastuti, Khabibi Khabibi, Pengaruh Penambahan Polietilen Glikol (PEG) pada Selulosa dalam Serbuk Tongkol Jagung (Zea Mays) terhadap Adsorpsi Ion Logam Timbal (Pb2+), Jurnal Kimia Sains dan Aplikasi, 17, 1, (2014) 1-5 http://dx.doi.org/10.14710/jksa.17.1.1-5

[16] Nita Kusumawati, Septiana Tania, Pembuatan dan Uji Kemampuan Membran Kitosan sebagai Membran Ultrafiltrasi untuk Pemisahan Zat Warna Rhodamin B, Molekul, 7, 1, (2012) 43-52 http://dx.doi.org/10.20884/1.jm.2012.7.1.105 